\title{
The Catholic Martyrs of The Twentieth Century: A Comprehensive World History- A Review Article
}

God made us to know, love and serve Him in this world so we could be with Him in the next.

\section{-Baltimore Catechism}

To read this book is to be astounded at the courage of Catholics. But first, a brief digression from martyrdom to cowardice. Described is Alfred Rosenberg as the chief "theologian" for Adolf Hitler. Rosenberg's job was to rephrase the New Testament into pro-Nazi ideas. Reading about Rosenberg made me think of many of today's non-martyr bishops and priests, including many Vatican II deformers. Those bishops and priests who march to the contemporary tune of the liberal press and media would clearly have groveled for Hitler. Such is the case for those who make nice by selling their soul. One cannot read this book without realizing what a despicable lot so many of our bishops, priests and other leaders (McBrien, Curran,Mahony, Weakland-none ever confused with Stepinac of Yugoslavia, Mindzenty of Hungary, Popicluszko of Poland or Agostino el Nur of Sudan). Unable to face down the mega press and media by remaining faithful to Rome, most liberal bishops and priests have confused "loving your enemies" with "sycophantic toadyism," or maybe it is just cowardice. (It cannot be ignorance because they all know what Rome expects of them.) Just call them "Rosenbergers." The worst thing about Catholics is "bad Catholics."

Robert Royal's book, Catholic Martyrs of the 20th Century (New York: Crossroads, 2000), is not about them. In contrast, almost all of this book describes what real bishops, real priests, as real Catholics did during the persecutions in Mexico, Spain, France, Ukraine, Soviet Russia, Nazi Germany, Albania, Romania, China, Africa, Korea, Eastern and Central Europe, Sudan and any Islamic country. To read The Catholic Martyrs of the 20th Century is to be embarrassed and mortified. The incredible heroism and faithfulness makes one shrink to minuteness. One quivers with guilt-ridden empathy at what those men and women did-the thousands of priests, nuns and laymen (male and female) who stood up for their faith against outrageous assaults and terrible tortures in the 20th Century.

There is Father Miguel Pro courageously proclaiming "Viva Cristo Rey" ("Long Live Christ the King") at his firing squad execution. He was one of the thousands of priests and religious Catholic supporters who were murdered during the 80 years of secular suppression in Mexico during which the American government supported the murderous tyrannical Federales but denied support to the suffering Catholics.

Volume 5 Issue 2 - 2016
Dr. Samuel A Nigro M.D*
Retired, Assistant Clinical Professor Psychiatry, Case Western
Reserve University School of Medicine, USA
*Corresponding author: Dr. Samuel A Nigro M.D, Retired,
Assistant Clinical Professor Psychiatry, Case Western Reserve
University School of Medicine, 2517 Guilford Road, Cleveland
Heights, Ohio 44118, USA, Tel: 216 932-0575; Email:
sam@docnigro.com
Received: October 15, 2015 | Published: January 27, 2016

The story of the youth Nijole Sadunaite of Lithuania demonstrates pre-Vatican II at its best and the Soviets at their worst.

A nun in Soviet Russia proclaims during her tortures: "I am a Catholic and I boast of it-a Dominican and proud! You have no right to condemn me for this because God is not head of a political party and because the teachings of Jesus Christ are not a political program, but a program of love and mercy?"

The sheer number of Soviet imprisonments is staggering and it included many Catholics. By 1934, the 3,300 Catholic churches and 2,000 chapels on Russian soil had been reduced to two active churches, primarily meant to serve foreigners as a public demonstration that Catholicism supposedly existed in Russia. The Catholic population along the Black Sea of 200,000 disappeared. Estimates of the number of prisoners overall in the Soviet Union begin at 19 million and at least 40\% died as a minimum number. Catholic monasteries were replaced in the Solovetski Islands by Russian camps consecrating these once sacred islands as a massive Catholic burial ground.

In 1941, 250,000 religious people were killed by the Soviets as they retreated when the Nazis invaded Ukraine. When the Nazis arrived, their extermination began where the Soviets left off. The Nazis were more anti-Catholic than anyone ever realized. More than 8,000 priests were killed by the Nazis with thousands incarcerated in camps. Father Andrew Graff Sheptytskyi, of the Ukrainian Catholic Church, worked against the Nazis in the 1940s to maintain a Church independent of any worldly power. He protested to Hitler about the Gestapo and protected persecuted Jews. When he visited towns and villages where 
Jews were living, the Jews greeted him by carrying the Scrolls as a sign of their respect. Sister Maria Restituta was a nurse-nun arrested after the doctor in her operating room accused her of “dangerous language?' meaning she expressed some opposition to Naziism. After 8 months of abuse, she remained openly faithful: "I live for Christ and I die for Christ." So they took her out and shot her. Often the camps heard the following command: "Jews and priests" are to do this or that or to fall out of their columns for special unpleasant treatment. "Jews and priests" were always coupled together because in the eyes of camp authorities, one could not be worse than to be a Jew or a priestor a committed Catholic. Over 3 million Polish Catholics died at Auschwitz before it was used for the murder of Jews. The response from Pope Pius XI's 1937 encyclical Mit Brennender Sorge, was greeted with such suppression by the Nazis that the good Pope could only say: "There is but one alternative left, that of heroism?' I suspect that half of the American bishops ("Rosenbergers"?) do not know what he was talking about. Then there is German Bishop Clemens August von Galen exhorting all to struggle against the Nazis. During a sermon about protecting children from the Nazis, someone stood up and shouted out, "What right does a celibate, without wife or children, have to talk about the problems of youth and marriage?" Von Galen wittingly reposted: "Never will I tolerate in this cathedral any negative reflection on our beloved Fuhrer!"

Then there is Franz Jagerstatter, who wanted nothing to do with "the Nazi gang." They tortured him and used the guillotine having him face up to watch the blade at his death. Knowing right from wrong, knowing truth, oneness, good and beauty, he could do that. Pathetic that so many of our clergy, bishops, leaders and lay people do not_But the actual number of the thousands of Catholic priests, nuns and laymen murdered by the Nazis will never be known.

After World War II, the Soviets once again took over murdering Catholics. There is Joseph Slippyi, Ukrainian Bishop, who was sent from one Soviet Gulag to another for years of incredibly hard camp life, torture and suffering-his strength was such that the Soviets laughably tried to tempt him in 1959 with an offer to make him the Orthodox Patriarch of Moscow if he agreed to break with Rome. He preferred to stay in the Gulag and in exile. By 1949, the Ukrainian Catholic Church, with 4 dioceses, 8 bishops, 2,772 parishes, 4,119 churches and chapels, 142 monasteries and chapels, 2,628 diocesan priests, 164 monks, 773 nuns, 229 seminarians and over 4 million lay people, was liquidated or disbursed and all Catholicism was gone. At the same time, the Uniates of Ukraine (who were part of the Roman Catholic Church) lost at least ten million dead to the Soviets.

In 1896, the Turks massacred Christians in the vicinity of a Trappist Monastery in Algeria. Over 140,000 Christians died within a few months by the order of the Sultan. In one town, 4,500 Christians died in two days.

The saintly Charles D. Foucald himself was murdered by a 15 year old Islamic madman. (The inability of Islamic people to tolerate anyone different from themselves is an incontrovertible sign of inferiority, if not satanism.)

Spain was the site of new catacombs of the 20th century. British historian Hugh Thomas is quoted: "At no time in the history of Europe, or even perhaps of the world, has so passionate a hatred of religion and all its works been shown." He was referring, of course, to the Spanish Republicans supported by the communists (and Americanliberals) against Franco (who was not a fascist regardless of liberal idiotic statements to the contrary). The Spanish Civil War resulted in the death of over 6,800 priests and religious, 13 bishops, and probably 800,000 Catholic laymen. Liberal Americans still celebrate their despicable role in all this.

Catholics and other Christians in Asian countries were incredibly faithful and martyr-like in overwhelming numbers. The chapter called "The Chinese Carnage" begins in 1900 with the Boxer Rebellion when the number of bishops, priests, nuns and lay people killed in China duplicated the number killed in Armenia by the Turks at about the same time. That is, scores of bishops, hundreds of priests and nuns and tens of thousands of Catholics brutally murdered. These numbers were to pale in 1948, when ten times that many would be killed by the Chinese communists.

In the last decade of the 20th Century, the Islamic government of the Sudan has murdered over 2 million Catholics and other Christians and probably enslaved as many. Agostino el Nur, a catechist in Sudan was tortured for four months: nails were driven into his head, his beard was pulled out, he was cut with a knife and his genitals were mutilated with pliers and he was crucified for 24 hours, tied to poles, while lighted cigarettes were put in his ears. Muslims openly threaten: "Convert to Islam or die like Christ."

\section{Robert Royal states:}

There is no other group of victims throughout history who so consistently faced terrifying ends with calm hope and sincerely forgave their persecutors. Martyrs rarely ever assume the posture of moral superiority toward their executioners-people that most of us would regard as inhuman monsters. The martyrs are aware of the evil in themselves and the redemption that has come to them from outside the usual human darkness. By the specific dynamics of martyrdom, the desire for vengeance and sense of superiority are ruled out at the beginning (Pg. 389).

Martyrdom comes with Christian joy if one is faithful to the One True Fold ("Rosenbergers" need not apply). The story of the martyrdom and persecution of Catholics in the 20th century dwarfs all others. What is amazing is the reason for such. The overwhelming question is "Why?" And the answer is that the transcendental commitment of genuine Roman Catholicism as instilled by good bishops and priests convey a matter, identity, truth, oneness, good and beauty enraging to those who cannot do the same. Preaching the transcendentals 
makes for conflicts with all those unable to follow. The hatred in those who would injure and kill Catholics is a contortion of their unconscious knowing it is impossible to be like real Catholics-to be oyous in the grasp of the hand of God by doing all for a higher value because one is in the Body of Christ, a member of the One True Fold and marching in transcendental freedom. Catholics preach: "We have Loving Truth; there is sin; join us, repent and he free, for God's sake." The hateful anti-Catholics say: "We have hate; since we cannot be like you, join us or die."

In the rough sea of life, the Church plods slowly as a solid edifice afloat and a haven for those who climb aboard...a Salvation Church, a Rescue Vessel. Perpetually, the creaky old, sworn at, besieged, constantly leaking, perpetually ruined, always sinking barque, no bone in its teeth, the Roman Catholic Church, with never less than one-twelfth of its crew in mutiny or incompetent, always enviously rejected with brutal intrusion of violent evil from those unable to accept her eternal basics, just keeps plowing along in the one direction flow of the Divine Substance, rescuing anyone who reaches out a hand, collecting sinners who have finally realized they have intrinsic value and worth in the sight of God and can return to Him in a plan of salvation.

No doubt, this is bewildering to those who would hate Catholics and the Church. But that too is because they are enraged that they are unable to be like genuine committed Catholics. (It is an overly compensated inferiority problem with reaction formation: They resent Catholic standards; they deny sin; and they deny Catholic achievements, all of which their unconscious wants to identify with. This is an example of most spontaneous hate: The hateful cannot tolerate anyone different so they demand all to be the same; i.e., like "them" when, in the unconscious, their deepest want is to be able to be like those hated).

\section{Postscript}

My review of Catholic martyrdom was begun before discovering Robert Royal's The Catholic Martyrs of the 20th Century. I started this analysis several years before because of the increasingly frequent special consideration given to documented victims such as survivors and relatives of those in the Nazi Holocaust and those related to slaves of over 150 years ago. In fact, there has been an unspoken victimhood contest between the black and the Jewish communities for some time wherein victimhood is used for monetary extortion as well as psychological exploitation by "untouchable," "poor-us," "don't tread on me" intimidation.
However, a factual description of the persecution of Catholics reveals that the Church lost more people and property to the Nazis than Jews ever did. Furthermore, slavery achieves a different perspective when one compares the deaths of 14 million black slaves by Muslims over 14 centuries (such that there are very few blacks left in Muslim countries) to the healthy legacy of 12 million black slaves in the west over four centuries (For example, of approximately 500,000 blacks imported into the United States to be slaves, 35 million exist today in the United States).

The Roman Catholic Church indeed is the most persecuted organization in history. if a victimhood contest is desired for propaganda and self aggrandizement purposes, the Church can even rightfully say it is second to noneandthatthepersecutiongoesontodayevenin theUnited States. While not as brutal as described in this article, the documentation of anti-Catholicism can be readily obtained from the Catholic League of Religious and Civil Liberties. If any group demands or believes reparations are due because of persecution and mistreatment, the Roman Catholic Church should be first in line. For what the Church deserves reparations is readily documented. Inspite of its obvious persecution in the United States, the Catholic Church educates over 2.6 million students annually at a cost of $\$ 10$ billion dollarssavingAmericans 18billion dollars; the Church alsoprovides 230 universitiesand colleges and 637 hospitals. The Church provides for the poor and deprived over $\$ 2.3$ billion dollars annually. Lesser but significant contributions have been ongoing for 200 years in the United States. For all the Church has done for all countries everywhere, every country owes it a huge amount of reparations.

In spite of persecution ongoing today in more subtle ways than overt martyrdom the barque of St. Peter continues. Jealous, thinking they cannot do it, the persecutors will always be there. But to them and to all those who hate the Church, I say: "Study the Church and find out the truth and love contained therein. Convert. You too can do it! Stop the persecution! You too can do it! You will find no greater joy!"

Finally, a specific set of educational materials needs to be disseminated about the facts of historical anti-Catholic persecution. These materials should be mandatory for all schools, public and private. A museum is needed in Washington, DC. Public monies must be allocated factually to clarify the persecution of Catholics throughout the centuries. There is a precedent for such. 


\begin{tabular}{|c|c|}
\hline DATE & DESCRIPTION \\
\hline $\begin{array}{l}70 \text { A.D. to } 135 \\
\text { A.D. }\end{array}$ & $\begin{array}{l}\text { Bar Cochba demanded all Christians join him (as Messiah) to fight a war against } \\
\text { Rome. He killed thousands of Jewish converts to Christianity because they } \\
\text { refused. Also, the "extermination prayer" was recited three times a day in all } \\
\text { Jewish services in order to identify Jewish converts to Christianity who would } \\
\text { refuse to say this prayer out loud. Jews were totally intolerant of the new Jewish } \\
\text { sect believing in Christ calling them minims. } \\
\end{array}$ \\
\hline $\begin{array}{l}\text { Pagan Rome } 64-67 \\
\text { A.D. - }\end{array}$ & $\begin{array}{l}\text { About } 25 \text { years of persecution by the psychotic Nero. Christians were thrown to } \\
\text { wild beasts in the arena. Others were dressed in clothing soaked in pitch and } \\
\text { sulphur and lit as human torches along the Appian Way while Nero raced by in } \\
\text { his chariot. It was illegal to be Christian in Rome and surrounding provinces. } \\
\text { Paul was beheaded three miles outside of Rome and Peter was crucified upside } \\
\text { down. } \\
\text { Casualties: Tens of thousands }\end{array}$ \\
\hline 117 A.D. & $\begin{array}{l}\text { Emporer Tragan celebrates his conquests by massacaring Christians with one } \\
\text { celebration lasting } 123 \text { consecutive days. } \\
\end{array}$ \\
\hline 155 A.D. & $\begin{array}{l}\text { The Roman Arena with Christians murdered including Bishop Polycarp } \\
\text { Casualties: Thousands }\end{array}$ \\
\hline 167 A.D. & $\begin{array}{l}\text { Year of the great plague with Christians being blamed }-- \text { at least } 3 \text { bishops } \\
\text { murdered in Asia Minor and Greece with Christians not killed condemned to hard } \\
\text { labor. } \\
\text { Casualties: Thousands }\end{array}$ \\
\hline 177 A.D. & $\begin{array}{l}\text { In Lyons, France, Christian community was mercilessly murdered with open } \\
\text { inhuman treatment and torture as roasting on iron chairs. }\end{array}$ \\
\hline & Casualties: Thousands \\
\hline 250 A.D. & $\begin{array}{l}\text { Decious the Emperor issued an edict which resulted in everyone being killed who } \\
\text { refused to make a public sacrifice to pagan idols. The Pope was killed and many } \\
\text { bishops along with many other Catholics. }\end{array}$ \\
\hline & Casualties: Tens of Thousands \\
\hline $\begin{array}{l}257 \text { A.D. to } 259 \\
\text { A.D. }\end{array}$ & $\begin{array}{l}\text { Valarian the Emperor condemned all Christian bishops, priests, and deacons to } \\
\text { death. Two popes were killed along with many other ministers and other } \\
\text { Catholics. }\end{array}$ \\
\hline & Casualties: Tens of Thousands \\
\hline 300 to 800 A.D. & $\begin{array}{l}\text { Arians did not believe that Jesus was "consubstantial with the Father" so they } \\
\text { killed Roman Catholics who did. }\end{array}$ \\
\hline & Casualties: Tens of Thousands \\
\hline $\begin{array}{l}303 \text { A.D. to } 311 \\
\text { A.D. }\end{array}$ & $\begin{array}{l}\text { The persecutions of Diocletian and Galarious--all Christians were removed from } \\
\text { public office, courts were closed to them, and Christian slaves were prohibited } \\
\text { cmancipation. All churches and Christian books were ordered destroyed. Many } \\
\text { were beheaded and slaughtered. Any Christian refusing hommage to pagan gods } \\
\text { was tortured and killed. The rest were imprisoned and sent to stone quarries. } \\
\text { Every known Christian was killed. } \\
\end{array}$ \\
\hline
\end{tabular}




\begin{tabular}{|c|c|}
\hline $\begin{array}{l}361 \text { A.D. to } 363 \\
\text { A.D. }\end{array}$ & $\begin{array}{l}\text { Julian, the Apostate extorted, imprisoned, tortured and executed Christians, } \\
\text { seizing churches and destroying them } \\
\text { Casualties: Tens of thousands }\end{array}$ \\
\hline 410 A.D. & $\begin{array}{l}\text { Alaric the Visigoth attacked Eastern Christianity and Constantinople } \\
\text { Casualties: Tens of thousands }\end{array}$ \\
\hline 452 A.D. & $\begin{array}{l}\text { Attila the Hun laid waste to all Christianity until he met Pope Leo } \\
\text { Casualties: Tens of thousands }\end{array}$ \\
\hline 453 A.D. & $\begin{array}{l}\text { Gaiserec the Vandal looted all of Christianity except for few churches which Pope } \\
\text { Leo persuaded them to leave untouched } \\
\text { Casualties: Tens of thousands }\end{array}$ \\
\hline 523 A.D. & $\begin{array}{l}\text { Persian pagans conquered Christian Armenia and Georgia } \\
\text { Casualties: Tens of thousands }\end{array}$ \\
\hline 523 & $\begin{array}{l}\text { Jewish Chieftain Dhu Muwas massacred some } 300 \text { Christians in Nigren in South } \\
\text { Arabia (Yeman) for refusing to accept Judaism } \\
\text { Casualties: Hundreds }\end{array}$ \\
\hline
\end{tabular}

MOHAMMEDISM 600 to 1683 and currently

\section{( Histerian kGikew}

1 622 Mohamuned went to Medina and began his militant religion which wars against all who do not follow him and vows no apostasy without exception. There is no separation of church and state but leaders are to lead in faith, in war and in government. Mohammed's legacy of malignant discontent with whatever they have and demonic appropriation of all they do not have, resulted in conquest of almost all Mediterranean Catholicism in Africa, the Middle East and Spain. Mohammedism persists with contemporary tinancing by Middle Eastern oil money, unable to satisfy its believers except when yelling like robots, demanding what all non-Islamic people have but still proclaiming Islamic culture is better even though they have almost nothing except what has been already appropriated, bought or borrowed from non-1slamic countries. It aprears people flec Islamic countries because there is nothing there except oil and the robotile enthusiasm of the ruling families" interpretation of the Koran, and you better parrot that or else. Muslims get almost everything else from the west: shoes, computers, weapons, machinery, medicines, you name it They even go to the West to get an education and they learn quickly to be fake Westerners to be replaced by the "anything goes" Muslim irrationality of the Koran when the time is right All information about Islam is from the Koran and the Hadith which are not allowed historical critical analysis as is civilized for all other religions. However. from the Koran and Hadith, the following can be found: Mohammedism was begun by Mohammed who, as a young boy, was raised by Aminah, a woman with strong occult like beliefs and was visited, she claimed by spirits or Jinns. He was raised in pre-Islamic pagan Arabia which worshiped the Kabah at Mecca. The Kabah had 360 idols, one of them being the crescent moon god, the chicf or high god: al-ilah. It or Ilah. Also, at the Kabah, there was a sacret magical stone which everyone ran around 7 times kissing it and then would run to a nearby wadi and "throw stones at the devil." The crescent moon god llah was said to have 3 daughters who were to be worshiped also according to Mohammed and the Koran (these are called the Satanic Verses). When Mohammed took over, he destroyed all the other idols leaving the crescent moon god who was the most important one to the pagans. Mohammed changed Ilah to Al Ilah, the Supreme God, and shortened it to Allah, apparently no longer to be a pagan god. Muslim records indicate all this including the fact that Mohammed had up to 22 "wives" including Aisha who was betrothed to him at age 6 with the marriage consummated at age 9 . In addition, he married the attractive wife of his adopted son in a rather controversial forcing way. As a young pagan, Mohammed had a miraculous vision that a heavenly being slit him open, stirred his insides, and then sewed him up. Mohammed was known to fall to the ground perspiring profusely with his body jerking and his eyes rolling back followed by a trance like state. Afterwards he would recite what had been told him during this supposed revelation. He often thought of committing suicide because he believed he was possessed by demons but at the age of 40 his wife convinced him otherwise. At age 40 he had a vision that he was prophet and apostle. He had shamanistic beliefs in which he communicated to Jinns of trees, rocks and waters of Arabia which he claimed were all under his control

The Koran and Hadith further record the following: Mohammed had elborate rules and rituals to earn Allah's forgiveness to be saved. Black people are always referred to as slaves and always as slaves of Mohammed. Mohammed murdered an old man who joked about the dirty forehcads of Mohammed's followers as they prayed on their knees with their head down in the dirt. The old man picked up dirt, put it on his forehead and said that this would be easier than putting one's head in the dirt and putting one's butt up as if ready for sodomy? Mohammed prayed for forgiveness of his sins and his ignorance, thereby admitting that he was not a divine omniscient sinless being. He dyed his hair red. He kissed and adored the black stone at the Kabah in Mecca. He believed in the power of the "evil eye." He believed in good and bad omens with the appearance of certain birds and other animals. Mohammed feared evil spirits would enter his body when he urinated or defecated. He feared strong winds meant that Allah's wrath was coming. He was seized with fear that the day of judgment had occurred when a solar or lunar eclipse occurred. He was superstitious about even numbers always avoiding them and even stipulated that one should always use an odd number of stones when cicaning one's self after defecating. 


\begin{tabular}{|c|c|}
\hline $\begin{array}{l}\text { Mohammedism - } \\
\text { Cont'd }\end{array}$ & 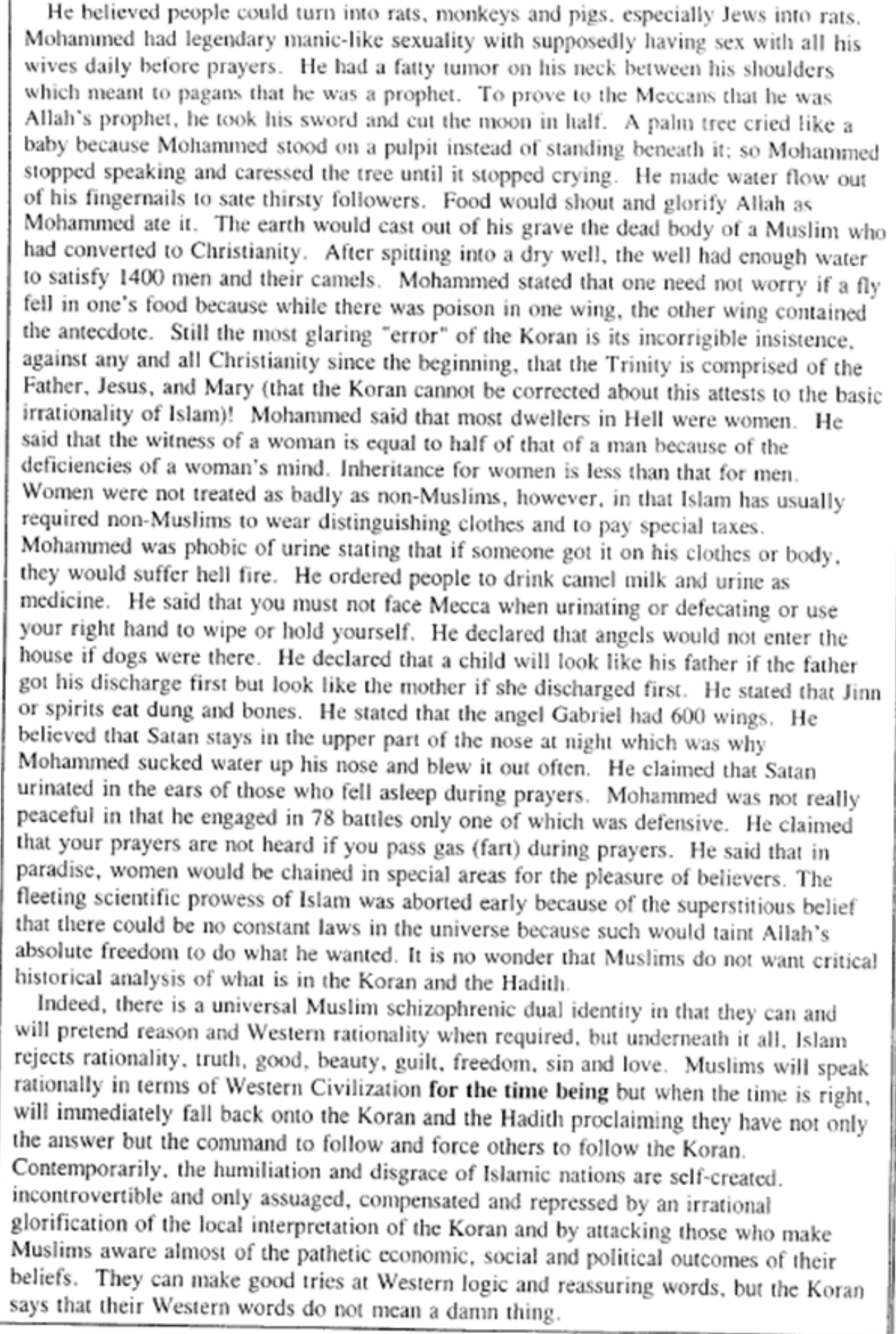 \\
\hline
\end{tabular}




\begin{tabular}{|c|c|}
\hline 600 to 1000 & $\begin{array}{l}\text { Muslims invade and conquer Asia Minor. the Holy Lind and all of Africa. The } \\
\text { crusades begin in } 1095 \text { (and end in 1683). In 922, the Muslim mystic al Hallaj } \\
\text { was decapitated for preaching that Allah was a loving God: the condemnation was } \\
\text { because he attributed the human sentiment of love to God. Of course the human } \\
\text { sentiment of violence is welcomed without repurcussions unless one resists it. } \\
\text { Casualties: Millions }\end{array}$ \\
\hline 700 to 709 & $\begin{array}{l}\text { Jewish communities in Spain invite Muslims to cross the straits of Gibraltar and } \\
\text { aid in Muslims conquering all of Spain. } \quad \text { Casualties: Hundreds of Thousands }\end{array}$ \\
\hline 846 & $\begin{array}{l}\text { Soldiers of Mohammed descend on Rome and destroy St. Peter's Basilica and St. } \\
\text { Paul's Outside the Wall. } \\
\text { Casualties: Tens of Thousands }\end{array}$ \\
\hline 1100 & $\begin{array}{l}\text { By } 1100 \text {, every Christian institution in Jerusalem and the Holy Land had been } \\
\text { ravaged and destroyed by Muslims. In the } 12 \text { th century, after } 5 \text { centuries of } \\
\text { Muslim conquering, the nonprovocative ancient Christian communities sought } \\
\text { help and the crusaders were formed to reestablish safety for pilgrims and others } \\
\text { who wanted to visit and remain in traditional Christian lands. }\end{array}$ \\
\hline 1169 to 1193 & $\begin{array}{l}\text { Muslim leader Saladin becomes master of Egypt and reconquers the Holy Land } \\
\text { from the crusaders. } \\
\text { Casualties: Hundreds of Thousands }\end{array}$ \\
\hline 1237 to 1242 & $\begin{array}{c}\text { Mongol hordes invade Prussia, Poland, Eastern Europe and the Holy Lands } \\
\text { Casualties: Hundreds of Thousands }\end{array}$ \\
\hline 1240 & $\begin{array}{l}\text { From the } 800 \text { 's to } 1240 \text {, the Vikings and the Danes were rampant pagans killing } \\
\text { and rampaging until both groups were defeated by Alfred of England } \\
\text { Casualties: Hundreds of Thousands }\end{array}$ \\
\hline 1240 & $\begin{array}{l}\text { Mongols march into Russia, Ukraine and Hungary. They persisted until } 1242 \\
\text { when Mongolian leaders withdrew because of domestic ruler problems in their } \\
\text { homeland } \\
\text { Casualties: Hundreds of Thousands }\end{array}$ \\
\hline 1250 & $\begin{array}{l}\text { Mameluks or Janissaries defeat the Mongols and the crusaders again. Janissaries } \\
\text { were the extremely well trained Caucasians taken from Eastern Europe every } 5 \\
\text { years when the Muslims would come in and inspect all } 7 \text { year old boys } \\
\text { kidnapping the ones they thought would make good mercinary slaves for Islam. } \\
\text { Casualties: Tens of Thousands }\end{array}$ \\
\hline 1282 & $\begin{array}{l}\text { The Eastern Orthodox Church funds and perpetrates the genocidal murder of } \\
\text { French Catholics in Sicily - every French adult and child including French } \\
\text { children in utero of Sicilian women, were killed. } \\
\text { Casualties: Tens of Thousands }\end{array}$ \\
\hline 1291 & $\begin{array}{l}\text { Islamic Mameluks destroy the Catholic knights and crusaders known as the } \\
\text { Templars destroying all Catholic presence in the Holy land. } \\
\text { Casualties: Hundreds of Thousands }\end{array}$ \\
\hline
\end{tabular}




\begin{tabular}{|c|c|}
\hline 1340 & $\begin{array}{l}\text { The whole of Western Asia Minor is conquered by Muslims seizing all valuable } \\
\text { property belonging to Christians holding them subservient unless converting to } \\
\text { Islam. The Ottoman Empire was to last for } 600 \text { years and the lands evangelized } \\
\text { by St. Paul were brutally uncivilized once again and put into an irrational anti- } \\
\text { scientific stagnant state. } \\
\text { Casualties: Hundreds of Thousands }\end{array}$ \\
\hline 1396 to 1683 & $\begin{array}{l}\text { The Ottoman Turks conquer Asia Minor, Cyprus, Greece, Germany and Turkey. } \\
\text { Islamic invasion ends with the defeat of the Ottoman Turks in Vienna in } 1683 \text {. } \\
\text { Casualties: Hundreds of Thousands }\end{array}$ \\
\hline 1443 & $\begin{array}{l}\text { Muslims sack Nice destroying much of it killing most of the men, selling women } \\
\text { and children to slavery. They did this for decades along the coast of Italy. } \\
\text { Casualties: Hundreds of Thousands }\end{array}$ \\
\hline 1453 & $\begin{array}{l}\text { The Muslims conquer Constantinople. Haji Sophia was converted to a mosque } \\
\text { with every hint of Christianity destroyed except the altar which } \\
\text { was left standing to remain barren to this day. The city was renamed Istanbul. } \\
\text { Mohammed II sacked Constantinople for } 3 \text { days as he had promised his men. } \\
\text { Over } 4,000 \text { Christians were killed. More than } 50,000 \text { others were seized, with all } \\
\text { but a few survivors were enslaved. } \\
\text { Casualties: Tens of Thousands }\end{array}$ \\
\hline 1480 & $\begin{array}{l}\text { Russia-Ivan III - stamped out freedom in education and attempted to destroy } \\
\text { Catholicism by incorporating the Orthodox Russian Church into the government. } \\
\text { Casaualties: Tens of Thousands }\end{array}$ \\
\hline 1480 & $\begin{array}{l}\text { The Turks assault the City of Otranto at the southern tip of Italy, capturing } \\
22,000 \text { people and selling them to slavery and killing } 12,000 \text {. Every cleric in the } \\
\text { City was killed and the Archbishop was sawed in two. } \\
\text { Casualties: Tens of Thousands }\end{array}$ \\
\hline 1480 & $\begin{array}{l}\text { The Ottoman Turks finished their conquest in Greece, the Balkans and the Black } \\
\text { Sea and are defeated at the Island of Rhodes by the crusading order of the } \\
\text { Knights of St. John of the Hospital who had been doing good works for over } 350 \\
\text { years. Against the odds of } 35 \text { to } 1 \text {, the Turks were defeated. But most of the } \\
\text { former Catholic property and lands were lost and almost all Catholics were killed. } \\
\text { Casualties: Hundreds of Thousands }\end{array}$ \\
\hline 1500 's & $\begin{array}{l}\text { The first Catholics in Japan were subjected to torture and death. The most cruel } \\
\text { torture was ana tsurshi which was to be suspended by one's feet above a manure } \\
\text { pit with one's face and head cut open until one bled to death. } \\
\text { Casualties: Tens of Thousands }\end{array}$ \\
\hline
\end{tabular}




\begin{tabular}{|c|c|}
\hline 1500 to Present & $\begin{array}{l}\text { Martin Luther (the father of Protestantism - } 1487-1546 \text { hegins lis obsessional } \\
\text { psychotic attack on the Church. Luther's background is quite consistent with } \\
\text { someone who would hate any and everyone. His father was an occultist believing } \\
\text { in Germanic witches, hobglobins and demons, all evident in the imagination of } \\
\text { Martin Luther whose visions are well documented. including occurrences of the } \\
\text { devil hurling "shit" at him with Martin throwing it back. By what was the worst } \\
\text { promise to God in history, he entered the priesthood because he promised he } \\
\text { would do so if he survived a terrifying thunderstorm as a young man. He } \\
\text { suffered from panic attacks; he was phobic being unable to look at a crucifix } \\
\text { around his neck; was terrified of damnation; and believed he could never be } \\
\text { absolved of sin. Then, while having a bowel movement on the privy, he } \\
\text { suddenly felt he had broken free of his own sinfulness not by Church sacraments } \\
\text { but by "faith alone." This resulted in a crisis for Catholicism. Luther attained } \\
\text { his power by iricorporating his religion into the state -- and protestantism has } \\
\text { almost always been a state created or supported puppet of the local governments. } \\
\text { Luther declared in 1520 that the Pope was worse than the Sultan. In } 1556,12 \\
\text { years after Luther's death, top Lutheran theologans at the Worms Collegia could } \\
\text { not even agree among themselves and broke up beginning the steady Protestant } \\
\text { incoherence, fragmatism, and anarchy to today. The legacy of Protestantism is } \\
\text { immense exemplified by the Calvanists destroying images and paintings in all the } \\
\text { churches of Antwerp with monasteries and convents destroyed and libraries } \\
\text { burned. In Flanders, more than } 400 \text { churches, monasteries and convents were } \\
\text { sacked and desecration took place. The bizarre craziness of some of the offshoots } \\
\text { resulting from Luther's diabolical heresy makes for unbelievable reading with } \\
\text { horrors against those who tried to remain with the Roman Catholic Church. } \\
\text { Luther's peasant revolt resulted in two years of civil war with the dead reaching } \\
250,000 \text { before it was over. The deaths due to Luther and his followers are } \\
\text { appalling. }\end{array}$ \\
\hline 1534 & $\begin{array}{l}\text { Henry VIII establishes the Act of Supremacy making him king of the English } \\
\text { church appropriating all Catholic property and power with the execution of those } \\
\text { who do not agree. } \\
\text { Casualties: At least } 85,000\end{array}$ \\
\hline 1559 to 1603 & $\begin{array}{l}\text { Queen Elizabeth I's } 44 \text { years of anti-Catholic tyranny results in a country } \\
\text { changing from } 99 \% \text { Catholic to } 99 \% \text { Church of England. } \\
\text { Casualties: Tens of Thousands }\end{array}$ \\
\hline 1570 & $\begin{array}{l}\text { The Turks conquer Nicosia, capital of Cyprus. After surrendering on reasonable } \\
\text { terms, the Muslims massacred thousands of soldiers and civilians selling most of } \\
\text { the women to slavery. One of the women. Almada de Roca was on a ship with } \\
800 \text { other Christian women to go to Istanbul where each would be sold to the } \\
\text { highest bidder to do whatever he wished with her. She got to the ship's powder } \\
\text { magazine with flint and steel and blew the ship up with everyone on it. Other } \\
\text { Christian women to be enslaved were not so lucky. } \\
\text { Casualties: Tens of Thousands }\end{array}$ \\
\hline
\end{tabular}




\begin{tabular}{|c|c|}
\hline 1571 & $\begin{array}{l}\text { The Turkish army bombards the large city of Marseille. The Venetian } \\
\text { commander surrendered the city with written pledge of life and liberty to all } \\
\text { inside its walls. Two days later, the Muslim commander flayed the heroic } \\
\text { Christian commander, stuffed his skin, dressed it in a Venetian uniform and } \\
\text { dragged it through the streets while ordering a massacre of all Catholics } \\
\text { remaining in the city. } \\
\text { Casualties: Tens of Thousands }\end{array}$ \\
\hline $1594-1603$ & $\begin{array}{l}\text { English begin the conquering Ireland with } 9 \text { years or warfare. } \\
\text { Casualtics: Tens of Thousands }\end{array}$ \\
\hline $1767-1960$ 's & $\begin{array}{l}\text { The Jesuits are expelled from Mexico by the Freemasons in a preliminary to the } \\
\text { French Revolution. Mexico was the cream of civilization thanks to the Jesuits. } \\
\text { In } 1575 \text {, books were being printed in Mexico City in } 12 \text { different languages and } \\
\text { before the first printing press had been set up in British America. Before the } \\
\text { foundation of Harvard, three Mexican universities cxisted. There was a medical } \\
\text { school at the Royal Pontifical University of Mexico } 200 \text { years before Harvard. } \\
\text { Before William Hunter opened the first school of dissection in England, } \\
\text { anatomical, surgical dissections were being taught in Mexico. The Mason's } \\
\text { impact then as now, is always anticivilized because it is anti-Catholic. The } \\
\text { persecution of Catholics continued to the } 1960 \text { s with the United States } \\
\text { government supporting Mexican government and embargoing any support for the } \\
\text { Catholics. } \\
\text { Casualties: Tens of Thousands }\end{array}$ \\
\hline 1792 & $\begin{array}{l}\text { The Freemasons create the French Revolution with a reign of terror by the } \\
\text { Committee for Public Safety which attempts to remove Catholicism. The anti- } \\
\text { transcendental Masons destroyed innumerable objects of beauty, religious and } \\
\text { otherwise. This was a self anihilating, self ethnic cleansing, fundamentally a } \\
\text { Catholic cleansing in all ways. Any Catholic holding fast to his faith was } \\
\text { executed. } \\
\text { Casualties: Hundreds of Thousands }\end{array}$ \\
\hline $1845-1852$ & English starve Irish Catholics \\
\hline 1896 & Turks massacre Catholics in Armenia \\
\hline 1900 & $\begin{array}{l}\text { Boxer rebellion in China: scores of bishops, hundreds of priests and nuns and } \\
\text { tens of thousands of Catholic laymen killed. } \\
\text { Casualties: } 40,000 \text { dead }\end{array}$ \\
\hline 1917 to 1988 & $\begin{array}{l}\begin{array}{l}\text { In Russia, Soviets imprison and kill Catholics with the destruction of } 3,300 \\
\text { churches, } 200 \text { chapels }\end{array} \\
\text { Casualties: } 5 \text { million } \\
\end{array}$ \\
\hline 1936 & $\begin{array}{l}\text { Spanish Civil War wherein thousands of priests, religious, } 13 \text { bishops and up to } \\
800,000 \text { Catholic laymen are murdered. Over } 20,000 \text { churches and chapels are } \\
\text { destroyed, almost half of those existing. This was basically a communist and } \\
\text { American effort against Catholic Spain. } \\
\text { Casualties: Hundreds of Thousands }\end{array}$ \\
\hline
\end{tabular}




\begin{tabular}{|c|c|}
\hline 1941 & $\begin{array}{r}\text { Retreating from the Nazis, the Soviets kill as many Catholics as they can. } \\
\text { Casualties: Hundreds of Thousands }\end{array}$ \\
\hline $1941-45$ & $\begin{array}{l}\text { Nazis try to destroy Catholicism and kill many Catholics beginning in Poland } \\
\text { spreading to all Europe. } \\
\text { Casualties: } 6 \text { million }\end{array}$ \\
\hline 1948 & Chinese communists take over. \\
\hline 1949 & $\begin{array}{l}\text { Ukrainian Catholic Church and Catholic Uniates are destroyed by the Soviets } \\
\text { Casualties: } 14 \text { million }\end{array}$ \\
\hline $1954-1975$ & $\begin{array}{l}\text { Southeast Asian Communists destroy the Catholic presence in Viet Nam and } \\
\text { environs. It is written that tens of thousands of Vietnamese Catholics were } \\
\text { beheaded because they refused to trample the crucifix. } \\
\text { Casualties: } 1 \text { million }\end{array}$ \\
\hline 1990 to Present & $\begin{array}{l}\text { Muslims in the Sudan enslave, torture and murder Catholics, Christians and all } \\
\text { who do not follow Islam. } \\
\text { Casualties: } 2 \text { million }\end{array}$ \\
\hline
\end{tabular}

The number of Catholics murdered for being Catholic since the Church was founded by
Jesus is at the very minimum 41 million. 